\title{
Solitude as a Problem of Human's Mature Choice
}

\section{İssanın Olgun Seçiminin Bir Sorunu Olarak Tekbașinalık}

\author{
OLENA ALEKSANDROVA ID SVITLANA KHRYPKO (D) \\ Borys Grinchenko Kyiv University \\ GANNA IATSENKO \\ National Shipbuilding University
}

Received: 19.05.2020 | Accepted: 14.07.2020

\begin{abstract}
The multiple contexts of solitude and its coherence with the constant of mature life choices are considered in the article. The phenomenon of solitude is presented in light of the embodiment of value determinant. The authors' understanding of solitude as spiritual handwriting is demonstrated. The polarity of solitude's representation as an issue of ability or inability to make a choice is considered. The authors' classification of different contextual types of solitude accompanied by a focus on values as a result of life choice is provided. The mutual influence of maturity and solitude as a potential stimulating source if creativity and self-assertion are actualized. The phenomenon of solitude is universal and inherent in the philosophy of life; solitude as a multi-contextual phenomenon characterizes human beings in the social environment. Nevertheless, having multidimensional, controversial and inexhaustible nature, it can be a creative or devastating factor. The Ukrainian context of solitude is briefly described.
\end{abstract}

Keywords: philosophy, solitude, loneliness, being in private, maturity, choice, values.

$凶$ Olena Aleksandrova

Borys Grinchenko Kyiv University, Faculty of History and Philosophy, Dep. of Philosophy 02034, Kyiv, Ukraine $\mid$ olena.aleksandrova@yahoo.com

\section{$凶$ Svitlana Khrypko}

Borys Grinchenko Kyiv University, Faculty of History and Philosophy, Dep. of Philosophy 02034, Kyiv, Ukraine|s.khrypko@kubg.edu.ua

$\triangle$ Ganna Iatsenko

National Shipbuilding University, IEDL, Department of Philosophy and Cultural Studies 54000, Mikolayiv, Ukraine|iats26or@gmail.com 


\section{Introduction}

Solitude is an a priori phenomenon that is related to any person to some extend (whether it is explicitly or implicitly, noticeably or unnoticed, severely or cautiously). A life is a way to self through knowing the person's internal world and meeting your "self". A life is an amazing mixture of extraordinary moments, unexpected strokes of fate, desperate loneliness and sadness. Each stage of life is characterized by the particular symbolic values and value priorities that are the embodiment of a choice. A choice is always up to a person and reflects value and motivational embodiment of his maturity. The absence of panic fear of solitude is one of the maturity's criteria. $A$ man is an orphan of Being. The spiritual side of orphanhood is highlighted by the flight of time: "a man is hidden in a shell of individual being outside of which there are solitude and world's acceptance. The shell separates a man from the rest part of Being", encloses him within his powered "ego" [Khamitov 2002, 2I], [Movchan 2009, 20].

Therefore, solitude is an extremely discussion, controversial, poly-vectored, multidimensional, poly-contextual and infinite phenomenon according to the ambivalent nature that is an embodiment of a unique, extraordinary human Self, which can lead to devastating self-destruction or appeal to human creativity and freedom.

Being a social creature, a man tends to joy of communication that is one of the main values and demonstrates dynamic of socialization, namely happiness and anxiety, beliefs and doubts, willing of selfrealization, mutual assistance, etc.

Communication, interaction is a gift of a contact that opens a way to people and self, reveals culture of a dialogue and knowledge of "other" via self, via a context of ability to say-hear-understandoppose. Communication generates the maturity of thoughts and expressions, relevance of silence and optimal self-sufficiency of a dialogue "friend-or-foe", "self-other", etc. [Khrypko 2019].

However, maturity in the light of acme spiritual being does not always involve a collective format of recognition, priority of "We" phenomenon. Maturity can contain a conscious necessity of solitude 
(being alone). Alienation or solitude (forced or deliberate) can become a basis of life, survival, spiritual growth, self-affirmation, etc. Solitude as a phenomenon of spiritual being is not always an opposite side of communication, whereas all crucial decisions are taken when a person is alone, in private with his "Self" accompanied by conscience on his way to himself...

The aim of the research is to consider the phenomenon of solitude in the light of choice and realization of presented value dimension. Furthermore, the problem of existence or absence of choice in the context of axiology of life is presented to demonstrate the concepts' polarity in solitude's displays. The authors' systematization of solitude dimensions with the focus on an intentional choice is represented. The dual nature of maturity and solitude phenomena as the main determinants of creativity and self-assertion is highlighted.

Methods. The complex of theoretical and empirical methods was used for achieving of the stated aims, namely descriptive method and interpretation, synthesis and generalization, hermeneutics methodology and method of implication.

\section{Research and Results}

A period of long-term or hidden solitude passes through everybody's fate, the scientific world is not an exception. Solitude as well as its displays is an object of numerous studies in philosophy, sociology and psychology. An exciting peculiarity of the related literature is the fact that each author considers a phenomenon of solitude according to the personal experience, understanding of its role and specific nature. Due to philosophical analysis of a range of studies solitude is regarded from different perspectives: as mood, feeling of discomfort, fear (sociophobia and anthropophobia), experience of loss, deficit of trust and affection, alienation or feeling of social hunger, pain of inadequate recognition, love, intimacy or genetic mark.

Solitude is unexpectedly discovered in the biographies of philosophers: rigorous asceticism of Diogenes, voluntary solitude of I. Kant, loneliness as painful suffering of G. Hegel, ailing isolation of F. Nietzsche, mature solitude of $\mathrm{H}$. Arendt, isolation of V. Frank1, abso- 
lute loneliness of O. Solzenitsyn, the hermit-pilgrim, philosopher G. Skovoroda, solitude nature of M. Gogol, melancholy connection to the native land and nostalgia of T. Schevchenko, a lost Ukrainian man as a psychological and ethnical portrait of a Ukrainian of $M$. Schlemkevych, ethnical and poetic solitude of L. Ukrainka, etc. The issue of solitude is mentioned in the philosophic works. It was transferred into the Middle Ages from the ancient ideas of Platonism and asceticism, where even "a cult of solitude as a condition of contemplated and intimate communication with God" [Kon I989, II2] was created. Communication with God is a pray. Hence, we could assume that the medieval period embodied a dimension of spiritual solitude, so called prayer solitude, meeting with God and ability to hear Him in private.

The considered issue has obtained numerous definitions from the philosophers of the Renaissance and Modern time (solitude is regarded as a feature of a unique man) via existentialism (solitude is regarded as metaphysical feature of human) to nowadays. For instance, I. Kon [Kon I986, 40-42] granted the description of "eternal and diverse" to solitude, W. Sadler and T. Johnson presented it as "an acute sense... that demonstrated fragmentation of the real main network of relations", M. Miceli and B. Morash described it as a reaction to the fact that "the individual social connections were not equal to an internal standard" [Labyrinths of solitude I989, 27, I72], C. Rogers and F. Whitehorn depicted it as an external mask that was a result of "alienation from person's own self" [Self-consciousness and protective mechanisms 2003, 275-276], S. Taylor and D. Sirs identified solitude as idle existence, discrepancy between aspiration and reality: "it is a feeling of subjective discomfort that we are enduring when our social relations do not have some crucial content" [Teylor Sch., Peplo L. et. 2004, 360], J. Fischer considered it as a destructive form of acceptance, abandonment, uselessness [Psychological encyclopedia 2003, 498-499].

E. Fromm addressed to solitude trough freedom, he argued that the development of individualization strengthened isolation, uncertainty; consequently, a human place in the world, the sense of his 
being became much more dubious. Simultaneously, a sense of powerlessness and unworthiness was increasing. Having become individuality, E. Fromm emphasized that we reached solitude and encountered the world with its dangerous and violence events alone [Fromm i998, 55]. J.-P. Sartre and other representatives of existentialism characterized solitude as a foundational basis for individual being. The modern Russian researchers define solitude as "something invisible... where the external circumstances do not have crucial meaning... a man can feel loneliness despite other people (friends, relatives, acquaintances) who can be near him..." [Schvabl I991, I7-I8, 36-37]. Olena Aleksandrova, Roman Dodonov and Vira Dodonova considered geo-political context of solitude's representation in the light of "historical trauma" [Dodonova, Dodonov, Aleksandrova, et. 2019].

The works of the Ukrainian philosophers Mikhailo Movchan and Nazip Khamitov are a hymn of solitude. The last one introduced a concept of meta-anthropology as a marginal level of masculine and feminine origins in a context of ambiguous human being where masculine and feminine sides of solitude can be separated that are considered as the determinants of isolation and orphanhood.

There are different terms of love in Greek to describe various shades of meaning, for instance Eros, ludus, mania, storge, pragma, agape, philia; likewise there are many synonyms for description of solitude (with positive connotation) and loneliness (with negative connotation) in Ukrainian language in contrast to English. There are following:

- Burlak, odynak, odynets (for male) odynachka (for female) celibacy;

- Isoliovanist' - isolation, forced loneliness;

- Samitnytstvo - spiritual vocation of solitude;

- Sam-na-sam - being in private;

- Samostijnytstvo - inclination to separatism, powerful, authoritative solitude;

- Samota - impersonal loneliness;

- Usamitmenia - voluntary wish for temporary solitude;

- Vidchuzenist' - principal solitude; 
- Vidludkuvatist' - painful anti-sociality.

The tendencies of powerful, authoritative solitude are considered to be inherent in the context of political life and Ukrainian mentality [Grygoriyv I94I]. Furthermore, poetical voluntary wish for temporary solitude (usamitmenia) and tendencies of individualism are the classical features of Ukrainian mentality [Khrypko 2003]. The idea of solitude can be followed in the Ukrainian anthroponomics, for instance in such surnames as Bezridnyk (without relatives), Burlaka (single), Nichiynyi (without close people), Odynak (single), Samitnyk (hermit), Syrota (orphan), Vdovets' (widower), etc.

Generally, the resourceful base of multidimensional display of solitude can be the whole literary heritage of the nations of the world, all cinematographic material, etc. Any piece of work (fiction, non-fiction, letter, etc.) is written in private. Moreover, any author has his own experience of solitude that is "reflected" in a content of fiction or philosophical work.

Any human life contains different degrees of philosophical solitude in a unique variant of representation at a micro level.

The motivation of the study was the authors' interest in polyunity of solitude's issue in the light of mature person's choice regarding philosophy of maturity and philosophy of solitude.

\section{Discussions}

A man comes into the world in private... and leaves it in private. A moment of transition into a mysterious dimension of being is something fearful. The moment contains the depth and glory of solitude, even a part of which is not described by the secular discourse. This dimension of solitude is almost the only that contains a factor of will and conscious choice: "a man is a single creature who understands that he comes to the world without his will and leaves it despite his will" [Varava 2009, 4], [Lytvak 200I].

Solitude is a state, process, fact, action, reason, result, feeling, impression, criterion, and qualitative meaning of a criterion... A universal definition of solitude does not exist, according to the statement of M. Movchan, it belongs to "the range of concepts, meaning 
of real life that seems to be presented even in everyday routine, nevertheless, such transparency is misleading, it conceals the complicated and controversial character that is beyond a rational analysis" [Movchan 2009, 8].

It should be mentioned that solitude is a universal issue; its existence corresponds to humanity existence in cultural, historical and regional aspects and correlates with human memory. The issue is "eternal as it does not depend on social, economic formations, but is inberent in all civilizations" [Movchan 2009, 8].

Any type of solitude certainly includes some other contexts of its manifestation; however, we will try to systematize the phenomenon with highlighting an indication of value choice.

Stereotypical views of loneliness includes the negative contexts of understanding, for instance forces isolation, explicit introversion, anomie, depression, minimization of communication, losses, lack of the stable contacts with a family, friends, colleagues, alienation, forced limitation of contacts, vivid anti-sociality (sociophobia), melancholy (non-availability of the desired), bidden or open terrible fear of being alone (in private because of boredom-tedium), mirror image of an illusion (e.g. a man makes his plans, considers... but they are actually idle), unbearable feeling of "loneliness on the brink", etc.

Solitude has internal (metaphysical) and external aspects of manifestation according to the stereotypical division into internal (stable) and external components (generally accepted social beliefs). Robert S. Weiss considering the issue of solitude mentioned: "the defense mechanism was triggered: the researchers who minimized or rejected their personal solitude, ignored solitude of other people; and above all, they did not want to be considered as men who were suffering from loneliness" [Labyrinths of solitude I989, II5]. The Ukrainian researcher $M$. Movchan draws attention to the typical factor of disharmony in his interpretation of the phenomenon: "solitude is a state... that reflects some form of self-consciousness and demonstrates misconnection of the internal world as well as contains the experience of being alone, subjective impossibility or reluctance to accept an adequate feedback of self-recognition from other people” [Movchan 2009, 21, 27, 246]. 
The value part of solitude is minimized in a stereotypical format; moreover, factors of enforcement, in contrast to a personal conscious choice, prevail. Nevertheless, we can affirm that despite an acute, ruin and alien format of forced loneliness, a man can continue his life under the given circumstances and saves his "Self" when he has chosen life and value of life. A choice always depends on a person. Life is a marker of choice. The acutest format of forced loneliness, isolation can become a step towards moral destruction as well as a source of spiritual growth and revealing the best human qualities. Due to the folk wisdom, the men of light are brighter in the dark. Actually, there is a well-known aphorism: "a friend is someone who comes to you when the whole world leaves you".

Loneliness as a trauma is the most hazardous display of the abovementioned phenomenon. Post-traumatic stress disorder (PSD) is a classical embodiment of it; it is a condition "beyond the realm of possibility" according to the classical definition of $K$. Faspers. The phenomenon of PSD has several stages. I. Anxiety (outbursts of emotions, fear, anger, mobilization of all sides of "Self" for escaping or fighting). 2. Resistance (access to an optimal mode, attitudinal analysis of a situation... The stage continues to the end of stress or exhaustion. Someone can endure it for days, weeks or even months). 3. Exhaustion (powers end, a man is morally and physically exhausted, tired, experiences mental and physical inhibition, begins to make mistakes. Immunity system collapses,... there are some depressive reactions, loss of motivation, apathy. If there is no opportunity to release from stressful conditions and recover, it will result in death) [Survival School], [Post-traumatic stress Vol. II,I42-I58].

Any kind of stress is a way for a new self, on condition that a right choice has been made. "A life comprises extraordinary moments and everything else" - the expression is not an axiom; nevertheless, it is not without truth. "The moments" are something crucial at the level of "Self". They are in the memory, human identity is comprised by them, they do not permit to fall, reach breaking point..., and actually they are life. The brightest moments, the most interesting people come into a human's life during a storm. It is time of turbulence, 
crisis, when a life is divided into two periods: "before" and "after". It is time when a character is forming. It is time when a person can meet his true "Self". We can confirm to a certain extent that it is time when a man is able to reach the state of acme (from Greek $\alpha \kappa \mu \eta-$ a peak, maxim, the highest degree of something), the highest potential in his development and representation [Khrypko, S., Iatsenko G. 20I7, I49].

The universal psychological and philosophical constructions or methods of recovery from PSD do not exist. The phase "I know myself" makes sense. Someone needs communication, someone requires solitude and rest. Someone is in need of a doctor; others want children, relatives to be near them. Someone has a wish to speak, others want to hide from all and read. Someone needs to forget everything to stay alive; others are in need of remembering. A victim of violence remains miraculously alive, a victim of assassination, a witness of a fire in his own house, a witness of a horrible murder of his mother, etc. experiences loneliness to a greater extent than a group of refugees from occupied territory. The examples have nothing in common with publicity. " $A$ mother, who has lost bis child at war, will never speak in a language of the winner" - the words of Romen Rolan aptly underline the crucial issue - solitude is a deep private mystery, everyone has his own scars and handwriting of solitude. In addition, every nation has its own "historical trauma" [Dodonova, Dodonov, Aleksandrova, et. 2019].

According to folk wisdom - "The darkest night ends with a sunrise". A person might have gone through a stressful situation to understand the highest meaning of life, something vital to survive and live for it, to remember everyone who is near him. The following trinity goes through a fate of everyone: a crisis of solitude - life as a teacher values as a choice. There is a deep meaning in the words of mentioned dialogue:

“- When you have become over the edge..., you have only two ways: to fall down or take flight in the sky..."

- However, men cannot fly - it is obvious... 
- Try, try at least... and you will see the light!" [Post-traumatic stress 2017, Vol.2, I42 -154]

Solitude in the light of self-sufficiency that is self-preservation and a powerful step towards the recovery of a condition connected with "ash of life" is vividly described by Sir Joseph Rudyard Kipling in hispoem "If":

"If you can keep your head when all about you

Are losing theirs and blaming it on you,

If you can trust yourself when all men doubt you,

But make allowance for their doubting too;

If you can wait and not be tired by waiting,

Or being lied about, don't deal in lies,

Or being hated, don't give way to hating, (...)

(...) you'll be a Man, my son!"

Solitude as a value choice is a positive side of voluntary solitude that is connected with the existential search of personal optimal state and even more is natural normal condition of human being.

Life is a kaleidoscope of decisions. Personal decisions are taken in private; the crucial choices are not accepted in the noise or roar of the crowd (in this case they are not personal and are taken under the pressure). Even acute feelings of pain and fear that accompanied a state of solitude can carry a positive connotation and be valuable for the life-affirming acts. "Love is an ability to take on the pain of other man" according to the eastern wisdom. It is relevant to address to Sir Joseph Rudyard Kipling in this context: "The most honorable kind of fear is fear for other person's fate". A man is real when he is alone. The masks and artificial images are unnecessary in solitude. Pain and fear in the state of solitude draw attention to the value essence of "Self". For instance, the human nature is revealed in the state of uncontrollable mental condition (mind, intellect, consciousness cannot help in this case). If a person is tolerant of stress, he will consciously demonstrate value of life (by his word, action or deed) at the last minute, on the edge of non-violent death. Hence, solitude is an indicator of value of life and a will to live. 
Solitude as vocation occupies a separate position in the manifestations of the phenomenon. This is a powerful dimension of solitude as it includes such forms as besychasm (from Greek $\dot{\eta} \sigma \breve{\chi} \chi \dot{i} \alpha-$ tranquility, silence, solitude). It is the Christian mystical worldview, old tradition of spiritual practices that includes one side of the Orthodox asceticism. The adherences of the practice of "existential prayer", that is a mean of communion with God according to the grace rather than nature, obtain a name - the great recluses. They demonstrate the unique spiritual practices of solitude and prayer. A prayer is communication with God. Therefore, solitude is not absolute and has nothing in common with loneliness as it is accepted in the secular world. The Catholic tradition also has the same examples: Servants of Saint Mystery and Clemency (AASC - Sorores Adoratrices Ancillae SS. Sacramenti et a Caritate) and Devotees of Jesus's Blood (ASC Sorores Adoratrices Pretiossimi Sanguinis) [Annuario Pontificio 2003]. The nuns are in a state of permanent payer that is their vocation.

The similar mystical tradition is in the Sufi culture. "So many souls - so many ways to God" - a blind dervish says to a little girl in their way across a desert. "Someone, who has a vocation, has never lost his way"; "Are you going to walk alone? - I have found my way... Someone with faith has never lost his way", Someone, who walks, knows his way”; "A day of death is a wedding day with Eternity and is the most important day in life"- even this minimum of citations from the best piece of cinematographic culture of the Sufi "Bab'-Aziz - Desert Trilogy" fascinates people by appealing to "other" solitude being in the eastern cultural tradition. Two men are firmly going through the ocean of sand... as they have vocation [Bab' Aziz].

A thirst for solitude is an integral part of all world religions. $M$. Movchan concludes that "the issue of solitude is reflected in the religious texts trough seclusion. Leaving the secular business, solitude that requires internal concentration and elimination of passion is prior for bermit's life" [Movchan 2009,IO-II]. Simultaneously, a focus on the Highest Essence is the main demand and "light" of all world religions. The Ukrainian researchers interpret solitude as "a peculiar act of heroism 
that leads to salvation and communion with God... It is closely connected with the severe asceticism: spiritual triumph over body is one of the crucial principles of Christianity" [Schvabl I991, 24].

A lonely man identifies himself with a drop in an ocean that has been forgotten. According to the Sufi wisdom: "If we compare God to an ocean and a man to a drop than we can claim that a role of Sufism (as a teacher) to transfer a drop to an ocean. A mentor-teacher is like a river that comes to an ocean. A drop should rely on a river to be transferred to an ocean" [Nurbachsch 2009, 30]. Therefore, solitude can be a source of spiritual self-education as a life is a unique teacher. Life way is a way for self-knowledge, self-actualization and self-destruction, for other people and self [Khrypko 20IO, 266-267]. Being the embodiment of experience and memory, education is self-education since a man constantly learns every day, every minute, every moment... being in private with a face turned to the world.

To conclude we need to highlight the functional ambivalence of solitude's nature. It can be destructive feeling without any possible perspectives or escapes that will have a devastating impact on a personality in some cases. However, solitude can be a cathedral of spirit, crucial in the world's consideration, specific way of discovering new forms of freedom. Solitude can become a sign of aristocratic dignity and symbol of elevation of human essence. Solitude can provide consolation, it can shield from shallowness of being, ideological prodigality. Therefore, solitude is a mean of individual protection from forced social activity and simultaneously it is painful for someone who eagers intimate relations. It is desired and forced, it ruins and appeals... Everyone has his own levels and signs of solitude.

\section{Conclusion}

All contexts of solitude's understanding are subjectively different as life, memory and experience are unique and individual. A life is a work of solitude; there are the ideas of an internal voice inscribed on the tablets of memory... Solitude is spiritual and existential handwriting of a man. Solitude as handwriting can be esthetical calligraphic, harmonic and understandable, and on the contrary out 
of order, traumatic or incomprehensible. We need to conclude that despite different and interesting interpretations, definitions, classifications, everyone has his own solitude. Something that has inscribed in personal memory, experience and fate, something that has touched "self" is crucial for every person. Solitude is a deeply private sphere of human being. The scars of loneliness are unique for every buman. Mature solitude is a deliberate value choice. The values are the meaning of a word from which a life begins when it starts fresh. Moreover, it starts in private.

\section{References}

Annuario Pontificio (2003). Libreria Editrice Vaticana, Città del Vaticano.

Bab' Aziz. Desert Trilogy. - Director: Nacer Khemir. Recovered from https://www.youtube.com/watch?v=V8aA5 $\mathrm{EH}_{3} \mathrm{Xko}$

Dodonova, V. I. \& Others (2019). Strategy and Tactics of Behavior of Subjects and Objects of Historical Trauma. Analele Universitatii din Craiova, Seria Istorie, No. 2 (36). P. I53-I64.

Fliorko, L. (2006). Human Solitude as a Problem of Modern European Philosophy. (PhD Studies). Lviv: Ivan Franko Lviv National University.

Fromm, E. (1998). Escape from Freedom: Man for Himself. Translated from English. Minsk.

Grygoriyv, N. (194I). Ukrainian National Character. Winnipeg: Manitoba.

Hesychasm (2007). Literature Encyclopedia, 2 vols. Composed by Yu. Kovalyv. Kyiv: Academy, Vol. I, 439-440.

Khamitov, N. (1995). Philosophy of Solitude: Solitude Male and Female. Kyiv: Scientific Thought.

Khamitov, N. (2002). Philosophy of a Man: From Meta-physics to Meta-antropology. Kyiv: Nika-Center.

Khrypko, S. \& Iatsenko G. (2017). Communicative Component of Axiology of Education as a Spiritual Phenomenon and Praxeological Tool of PostTraumatic Stress Elimination in the context of War. Post-Traumatic Stress: Adults, Children and Families in the context of War. Materials of International Interdisciplinary Assembly, 3 vols. Warszaw-Kyiv, vol. 2, 4I2-428.

Khrypko, S. \& Omelchenko G. (2019). A Phenomenon of Mature Solitude as an Embodiment of Life and Work of Hannah Arendt. The Materials of Scientific Conference: Kyiv Philosophical Studies, May I6-I $7^{\text {th }}$, 220-224. 
Khrypko, S. (2003). Spiritual and Religious Displays of Ukrainian Mentality. (PhD Thesis). Kyiv: National Pedagogical Dragomanov University.

Khrypko, S. (2010). Axiology of Education as a Mystery of Vocation and Spiritual Essence of Being. Philosophy of Education, Vol. I-2 (9), 252-27I. Recovered from Аксіологія освіти як таїна покликання і духовна сутність вартості буття.

Kon, I. (I986). Multi-Facia Solitude. Knowledge-Power, vol. I2.

Kon, I. (1989). Searching for Yourself: Personality and His Self-Consciousness. Moscow. Labyrinths of Solitude (1989). Trans. N. Pokrovskyi. Moscow.

Lytvak, M. (200I). Psychology of Solitude. School Psychologist, November 344.

Montaigne, M. (2005-7). Essais, 3 vols. (Trans. A. Perepada). Kyiv: Spirit and Letter.

Movchan, M. (2009). Solitude as a Phenomenon of Human Being: Monography. Poltava: RVV Pusku.

Nurbachsch, D. (2009) Conversations about the Sufi Way. Moscow: Rieltiweb.

Post-Traumatic Stress: Adults, Children and Families in the context of War (2017).

Materials of International Interdisciplinary Assembl, 3 vols. Warszaw-Kyiv.

Psychological Encyclopedia (2003). Ed. P. Corsini \& A. Auerbach. St. Petersburg.

Schlemkevych, M. (1954). Lost Ukrainian Man. New York: Keys.

Schvabl B. \& Dancheva O. (1991). Solitude: Social and Psychological Problems. Kyiv.

Self-Consciousness and Protective Mechanisms of a Person: Anthology (2003). Samara.

Skovoroda, G. (I973) Complete Collection of Works, 2 vols. (Ed. S. Perevertun). Kyiv: Scientific Thought.

Skovoroda, G. (1983). Poems. Songs. Anecdotes. Dialogues. Tractates. Parables. Prose Translations. Correspondence. Kyiv: Scientific Thought.

Survival School in the context of War (2019). Part 3: The stages of Stress. Recovered from http://www.chasipodii.net/mp/article/2905.

Teylor Sch., Peplo L. et. (2004). Social Psychology. St. Petersburg.

Varava, L. (2009). The Peculiarities of Personal Loneliness in the State of Social Deprivation. (PhD Studies). Kyiv: The Institute of Psychology named after G. S. Kostiuk of Ukrainian Academy of Pedagogical Sciences. 
Öz: Olgun hayat seçimleri ile sabit yalnızlık ve uyum ile birden fazla içeriği madde olarak kabul edilir. Yalnızlık olgusu, değer belirleyicisinin somutlașması ıșığında sunulur. Yazarların yalnızlı̆̆ı manevi el yazısı olarak anlamaları gösterilmiştir. Yalnızlığın temsilinin polaritesi, bir seçim yapma yeteneği veya yetersizlik sorunu olarak kabul edilir. Yazarların, yașam seçiminin bir sonucu olarak değerlere odaklanmanın eșlik ettiği farklı bağlamsal yalnızlık türlerinin sınıflandırılması sağlanmıștır. Yaratıcılık ve kendini onaylama gerçekleșirse, olgunluk ve yalnızlı̆ıın potansiyel bir uyarıcı kaynak olarak karșlıklı etkisi. Yalnızlık olgusu evrenseldir ve yașam felsefesine özgüdür; çok bağlamlı bir fenomen olarak yalnızlık, sosyal ortamdaki insanları karakterize eder. Bununla birlikte, çok boyutlu, tartışmalı ve tükenmez bir doğaya sahip olmak, yaratıcı veya yıkıcı bir faktör olabilir. Ukrayna yalnızlık bağlamı kısaca açıklanmıștır.

Anahtar Kelimeler: Felsefe, tekbaşınalık, yalnızlık, özel olmak, olgunluk, seçim, değerler. 
